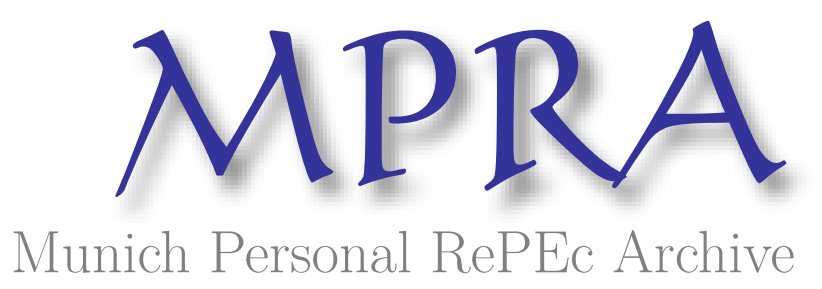

\title{
The Valencian Linguistic Conflict: Dialect or Regional Language? Instrument or Argument for the Catalans independence?
}

Buda, Mariana

University of Oradea

2015

Online at https://mpra.ub.uni-muenchen.de/91407/

MPRA Paper No. 91407, posted 17 Jan 2019 17:21 UTC 


\section{The Valencian Linguistic Conflict: Dialect or Regional Language? Instrument or Argument for the Catalans independence?}

Mariana BUDA ${ }^{1}$

Abstract: One of the controversies in the Spanish Culture is about the status of the Valencian Language. There are a few of politicians which affirm that the Valencian is a regional language, independent and unique. There are others that state that the Valencian is only a dialect issued from the Catalan. The aim of this article is to stress both parties and to express our point of view about the problem. Not less important is to see this question in relation with the everlasting wish of Catalans for independence.

Key words: Spain, Catalan, Valencian, the culture of region, regional languages, dialect

The Valencian linguistic conflict, often called by the sociolinguist Rafael Ninyoles i Monllor in his book Conflicte lingüístic valencià, the Valencian sociolinguistic conflict, is an expression that has to do with the conflict between the use of Valencian language and Catalan language on the territory of the Comunidad Valenciana in Spain. Otherwise, this expression it refers to the controversy regarding the identity of Valencian language and its relation with the Catalan language. There is a theory which supposes that the Catalan was imported in the region of Valencia and so the Valencian is just a dialect of the Catalan language and not a language. As in every sort of conflict, there are two opposed ideas and conceptions: the Valencian Nationalists who want to preserve and to promote the linguistic and cultural personality of the Valencian Language and the pro-Catalans which ideals would be to consider the Valencian as a dialect and to unify it with Catalan in order to constitute a unique language. Without any doubt, this linguistic conflict can and has to be related with the process and the desire of independence of Catalan people.

\section{General aspects. Legal overview}

Looking at the Spanish Constitution from 1978, where the status of regional languages is mentioned, in the Article 3.3 the linguistic diversity in Spain is recognized: "La riqueza de las distintas modalidades lingüísticas de España es un patrimonio cultural que será objeto de especial respeto y protección" . Even if the Regime of Franco tried to unify the languages spoken by the Spanish people and to impose the Castilian for all the inhabitants of the country, the speakers of regional languages continued to use their languages at home and among close friends and to transmit their culture to the children. As a result, due to the activity of some private institutions, that continued studying and promoting their use, the regional languages in Spain survived and were preserved. ${ }^{3}$

Officially, several Autonomous Communities in Spain have legal statutes providing protection to a number of different languages in Spain. Between them we should mention: the Principality of Asturias whose language is Bable, or Asturian dialect ${ }^{4}$, the Autonomous Community of Aragon, whose language is

\footnotetext{
${ }^{1}$ Teaching Assistant Phd at the University of Oradea, Department of International Relations and European Studies

2 The richness of the linguistic varieties in Spain is a cultural heritage that will receive special respect and protection, Spain Constitution, p.2

3 „Other Languages in Spain”, accessed May 25, 2015, http://www.donquijote.org/culture/spain/languages/otherlanguages-in-spain

${ }^{4}$ „Estatuto de Autonomía del Principado de Asturias”, Article 4.1, accessed May 25, 2015, http://www.congreso.es/consti/estatutos/estatutos.jsp?com=65\&tipo=2\&ini=1\&fin=9\&ini_sub=1\&fin_sub=1
} 
Aragonese or the Aragon language ${ }^{5}$, the Valencian Community whose language is recognized to be the Valencian $^{6}$, the Balearic Islands where is very common the Balearic dialect, very similar to Catalan.

In the Principality of Asturias, even if Bable is not recognized as an official language, it is protected by their Statute of Autonomy. This language isn't spoken only in Asturias, but also in the regions of Leon and Zamorra, reaching Miranda do Douro in Portugal. ${ }^{7}$ Regarding the Autonomous Community of Aragon, in their Statute is mentioned that all linguistic variation of Aragonese should be protected, as they are part of the cultural and historical heritage of the region. In the Statue of Valencia Autonomous Community (which includes the provinces of Alicante, Castellon and Valencia) it is mentioned that the two official languages are Valencian and Castilian. However, a linguistic conflict exists between the Valencian and the Catalan Languages, because the Valencians insist their language is a unique one, while the Catalans insist that the Valencian language is simply a regional dialect of Catalan. Even more, the Catalan Statute recognize the Aranese, a variety of the Occitan language spoken in the Northwest of Lleida, as a dialect of the people living in the area. On the same path, the Catalans would like that the Valencian Language has the same statute. This is why the topic is delicate and has more points of view. ${ }^{8}$

There is another curios case in Spain, that of the Castúo language, spoken in some parts of Extremadura. This language has influences from the dialects spoken in the regions of Leon and Rioja, but also from the regions of Aragon and the Basque County. ${ }^{9}$

Another interesting aspect, in addition to the linguistic variation in Spain that enriches the country, is the fact that the Castilian language has different dialects that have developed their own features. This is most obvious in different parts of Andalusia. For example, in the Western part of Andalusia, the language spoken shares many characteristics with the Spanish language spoken in the Latin America. An explanation could be the fact that the majority of the Spanish settlers to the New World were from this region. The case of the Canary Island is also interesting, because there is evident the linguistic influence of the Spanish from Western Andalusia, Portuguese and English. This mixture of influences remembers the history of these islands and their overseas travel between America and Europe.

In Spain, the linguistic situation is very rich and diverse. However, it is important to note that, despite all of these variations, Castilian is still the most commonly used language and it is the unifying language of the whole Spanish territory. ${ }^{10}$

\subsection{The Catalan Language}

The Catalan Language is one of the regional languages spoken in Spain, in the region named Catalonia, and it's one of the most spoken regional languages in Europe, with approximately 7 million speakers. ${ }^{11}$

During the time, the evolution of this language was curios, but flourished at the same time. The first text in Catalan dates from the $12^{\text {th }}$ century and it is called Homilies d'Organya. Later, in the $13^{\text {th }}, 14^{\text {th }}$ and $15^{\text {th }}$ century, the Catalan literature flourishes, first under the Provençal literature and later as the producer of its own thematic and formal resources. Later, from the $16^{\text {th }}$ to the $18^{\text {th }}$ century the Catalan

\footnotetext{
5 „Estatuto de la Autonomía. Estatuto de Aragon”, Article 4.1”, accessed May 25, 2015, http://www.estatutodearagon.es/estatuto_de_autonomia

6 „Estatuto de Autonomía de la Comunidad Valenciana”, Article 6.1, accessed May 25, 2015, https://www.boe.es/buscar/act.php?id=BOE-A-1982-17235

7 „Other Languages in Spain”, accessed May 25, 2015, http://www.donquijote.org/culture/spain/languages/otherlanguages-in-spain

${ }^{8}$ Ibid.

9 “El Castúo”, accessed May 27, 2016, https://sites.google.com/site/lacastua/el-castuo

10 „Other Languages in Spain”, accessed May 25, 2015, http://www.donquijote.org/culture/spain/languages/otherlanguages-in-spain

11 “Catalan Language. General Overview”, accessed May 28, 2015, http://www.orbilat.com/Languages/Catalan/Catalan.html
} 
literature underwent a period of decline in which the royalty and the political class of the time imposed different restrictions. In the $19^{\text {th }}$ century it emerged again with the movement called Renaixença, or Renaissance. Later, Pompeu Fabra was the first grammarian who effected the regulation and grammatical systematization of the Catalan language and unified spelling standards for its use. ${ }^{12}$

The Spanish Constitution from 1978 recognizes the use of both Castilian and Catalan languages as official in Catalonia, and since 1983 Catalan language is official in Balearic Islands as well. Catalan is also spoken in other areas of Spain and outside of the country. It is spoken in some parts of Aragon and Murcia, in Spain, but also in the French region Roussillon, in the Principality of Andorra and in the Italian city called Alguer, in Sardinia. It is the mother tongue of some 5 to 6 million people.

\subsection{The Galician Language}

Together with the Catalan Language, the Galician language is another Romance Language spoken on the Spanish territory and recognized by the 1978 Constitution as a regional language. It is spoken in Galicia, a territory in the North-Western Spain and was carried by the Christian conquerors outwards to present day Portugal.

The begging of the Galician dates from the $12^{\text {th }}$ century, when the language was called GalicianPortuguese. Later, on the $14^{\text {th }}$ century, after producing a body of literature, the language split into Galician and Portuguese, for historical and political reasons. ${ }^{13}$ However, the true renaissance of this language came in the $19^{\text {th }}$ century, when there is a notable production of literature, especially poetry. The language it's not spoken only in Galicia, where is co-official together with the Castilian language, but also it is spoken in some areas of Asturias and Castile-Leon. ${ }^{14}$

Today, there are about three million people speaking Galician, but it's very difficult to make an exact calculation due to its similarity to Castilian and the multiple interferences derived from a practically universal bilingualism. To this figure we must add the Galician communities living in Latin American countries that use it.

\subsection{The Basque Language}

The Basque Language or the Euskera is the language spoken in the northern central area of Spain. Euskera is the name of the language in the Basque language. Today, there are about 600000 speakers in Spain, but the language is not spoken only in Spain, because the Basque Country includes also some territory from France, called the French Basque Country, with approximately 100000 speakers. ${ }^{15}$

The Basque language is the only one which beginnings are not really traceable and who has a number of hypotheses. It has been suggested that the forerunner of the Basque language was introduced into this part of Europe by immigrants from Asia Minor at the beginning of the Bronze Age, but we know as well that the Basque and Castilian entered history together, since the first text preserved in Castilian, is also written in Basque. ${ }^{16}$ Also, it is known the fact that the Basque it's not a Romance language as the others regional languages in Spain.

Since the 1978 Constitution, the Basque Language it's recognized as official language in the Basque Country, together with the Castilian. The mountainous landscape of the region has contributed towards maintaining linguistic diversity, leading some linguists, based on the intercommunicative

\footnotetext{
12 "Pompeu Fabra", accessed June 1" ${ }^{\text {st }}$, 2015, http://www.lletres.net/pla/fabrapla2.html

13 „Other Languages in Spain”, accessed May 25, 2015, http://www.donquijote.org/culture/spain/languages/otherlanguages-in-spain

14 “Galician (Gallego)", accessed June 1 ${ }^{\text {st }}, 2015$, http://www.omniglot.com/writing/galician.htm

15 "Basque (Euskara)", accessed June $1^{\text {st }}, 2015$, http://www.omniglot.com/writing/basque.htm

16 „Other Languages in Spain”, accessed May 25, 2015, http://www.donquijote.org/culture/spain/languages/otherlanguages-in-spain
} 
difficulties found, to claim the existence of seven different Basque languages. To overcome this fragmentation the Royal Academy of the Basque Language was created in 1919, and in 1968, a standardized Basque grammar called batúa was adopted for official purposes. ${ }^{17}$

\section{The Catalan language's origins and history}

The legal basis of the language in Spain has been stipulated in the 1978 Constitution, mainly by Article 3 and in the Catalonia, Valencia, The Balearic Islands and Aragon Statutes of Autonomy. In Catalonia is implemented in 1998 by the law of the common languages (which replaces the law of 1983). In accordance with this legislation, Catalan is a specific language of Catalonia, Balearic Islands and Valencia and it is also an official language of these regions together with the Spanish. In the Andorra, in accordance with the Andorra Constitution, the Catalan language is the only official language. ${ }^{18}$

While speaking about Catalan's dialects, even if in the Middle Ages there is no evidence that the dialects existed, starting with the sixteenth century, dialects of Valencia and the Balearic Islands begin to be differentiated from the central area of Barcelona. However it has kept a certain degree of uniformity in the literary language which has continued to flourish. ${ }^{19}$

There are two main dialect groups in modern Catalan: Occidental, subdivided into North-West Catalan and Valencian; and Oriental, subdivided into Central dialect, Balearic, Roussillonnais and Alguerese (the dialect spoken in Alghero, Sardinia, where Catalan was introduced in the 14th century). Each of these dialects, except for Alguerese, is in turn divided into subdialects, of which up to eighteen have been identified. These various dialects differ only in minor respects (details of pronunciation, vocabulary, and verb conjugation) and are easily mutually intelligible. The dialectal differences are not usually reflected in the written language. The Institute of Catalan Studies is responsible for establishing and updating the standard language, which is based on the Barcelona dialect with some admixtures from Valencian. No one spontaneously speaks the standard, but it is used in writing and by the media.

Valencians - except for the intellectual elite - are inclined to consider their speech a separate language. For a number of historical and other reasons, a sector of the Valencian people are deeply distrustful, if not overtly hostile, to Catalans. The ultra-rightist party Unió Valenciana supports this sentiment, and among other things it called for linguistic secession by establishing a separate orthography. ${ }^{20}$

Looking back in the history, by the end of the $10^{\text {th }}$ century, the Catalan was already a formed language, with Latin origins. During the 13th and 14th centuries Catalan reached its high point of geographical expansion in the Iberian Peninsula through the conquest of the kingdoms of Valencia and Murcia. The language also spread around the Mediterranean through victory over the kingdoms of Majorca, Sicily, Sardinia, Naples, Athens and Neopatria in Peloponnese. Catalan came to be spoken, even if not always as a first language, in five states around the Mediterranean which were governed by Catalan dynasties. Due to the Royal Chancellery, whose style was strongly influencing for all Catalan writing, the prose of the 14th and 15th centuries was marked by a high degree of uniformity.

Catalan retained its vigor until the union of the Aragonese and Castilian crowns in 1474. After that, although mainly grammatical works appeared, it gradually entered a period of decline. Following the War of the Spanish Succession (1705-1715), Philip V abolished all the government institutions then existing in Catalonia and implemented Spanish laws. Catalan went through various periods of prohibition

\footnotetext{
${ }^{17}$ Iñigo Urrutia; Xabier Irujo, „The Basque Language in the Basque Autonomous Community (BAC)” in The Legal status of the Basque Language today: One Language, Three Administrations, Seven different Geographies and one diaspora, ed. Gloria Totoricagüena and Iñigo Urrutia, 2008, p.171, accessed June ${ }^{\text {st }}, 2015$, http://www.euskonews.com/0463zbk/ene_120.pdf

${ }_{18}$ „Cultura Catalana. Lengua” accessed June 1st, 2015, http://www.llull.cat/espanyol/cultura/llengua_catala.cfm

19 "CCatalan Language. General Overview”, accessed May 28, 2015, http://www.orbilat.com/Languages/Catalan/Catalan.html ${ }^{20}$ Ibid.
} 
and even of repression. The Catalan renaissance began in the late $19^{\text {th }}$ century with the economic progress of Catalonia. ${ }^{21}$

\section{The Valencian language's origins and history}

The Valencian language derives from the Latin language, brought in the area by the Christians colonists in the former kingdom of Valencia. There are three theories related with the origins and the evolution of the Valencian language.

The Mozarabist hypothesis or the Valencians theory, which it's based on the thesis that Valencian is an independent language, issued from the vulgar Latin, as a result of an isolated evolution. That romance language was diversified by Arab elements and influenced by the Spanish language - Aragonese and were precisely the Mozarabs who kept this language during the Arab domination, practicing the use of Arabic for official business and Romance at home. There are proofs that demonstrate that when Valencia was reconquered by the king Jaime I, the language still had vitality and the inhabitants, even if they were converted to Islam, they were still practicing the bilingualism. ${ }^{22}$

The second theory is the Repopulation theory, or the Pancatalan theory, which is totally opposed to the previous one. The followers of this theory consider the Valencian a variety of Catalan, brought to the Valencian lands during the Reconquista by the Catalan resettles. In this opinion the Islamic invasion caused the complete loss of the roots and the existing culture before and therefore of the language. In favor of this theory are some Catalan institutions, such as the Institute for Catalans Studies. ${ }^{23}$

The third theory, called the Occitan theory don't have to many followers. The main hypothesis of this theory consists in the assertion that the Valencian language is part of a set of Occitan languages, romances, interrelated, which have a number of similarities. According to this theory, the medieval poets imposed their culture on the inhabitants of the Kingdom of Valencia. ${ }^{24}$

Probably the origin of Valencian language is a mixture of these three theories. Supposing that the Valencian language is an Arabic dialect influenced by the Occitan language and the Romance language, which are dialects of Latin language, it is probably the most as close to reality as possible.

Until the XIII century, the term valencian meant inhabitant of the Romanian Colony Valentia, founded in 138 B.C., when the Muslim domination recalled it Balànsiya. Today's Community of Valencia derives from the Kingdom of Valencia which had been united with the Kingdom of Aragon in a third realm independently driven by King Jaime I of Aragon, along with the Reconquista of 1238. During this time, the region of Valencia enjoyed a high degree of autonomy. This is due to a clever system of institutions and laws, adopted in 1240. In the sixteenth century, the inhabitants of the Muslim faith have been obliged to convert to Christianity or to leave the province. The new inhabitants of this region were mainly Catalans. Along with them they brought as well their language, which spread in the area of Valencia and has become known as Valencian. ${ }^{25}$

The Kingdom of Valencia has lost its autonomy in 1707 by the decree Nueva Plant, during the War of the Spanish Succession (1701-1714), when King Philip V of Spain subordinated all federations of Aragon Kingdom directly to the Castilian Crown. As a result, the system of laws adopted in 1240 has been abolished, and valencian language has been prohibited at an official level and in education. Spanish becomes the official language and has been accepted by the local elite. The Valencian was still used at informal level, but remained widespread. Ethnic identity of the valencian population has started to change

\footnotetext{
21 Ibid.

22 „Origen del valenciano”, accessed June $2^{\text {nd }}, 2015$, http://www.idiomavalenciano.com/origen-del-valenciano.html

${ }^{23}$ Ibid.

24 Ibid.

${ }^{25}$ Höfer, Karel (2012): Valencian Identity, Language and Language Policy, alppi.vedeckecasopisy.cz/publicFiles/00186.pdf, accessed June 10, 2015
} 
in the nineteenth century in a regional identity. This new identity was not in conflict with the national Spanish identity, and it was a fair competition from a political point of view for the Spanish nation. ${ }^{26}$

During the second Spanish Republic (1931-1939) there have been different attempts to restore the autonomy, but these have been stopped by the Spanish Civil War (1936-1939). In March 30, 1939, after the fall of Catalonia and the majority of the territory of the Republic, Valencia surrendered in front of Franco, and this meant the end of the war. Franco started his dictatorship. For Valencia, as well as for the rest of Spain, has followed a tough period. Although the anti-separatist measures were quite easy in the area of Valencia, there were economic difficulties due to isolation of Spain, and political and economic issues, for its connections with the fascist regimes. After a dictatorship of 36 years, Spain has become a decentralized state as a result of the establishment of democracy. Spain was divided into 17 autonomous regions, one of them being the Valencian Community. ${ }^{27}$

\section{The Valencian Linguistic Conflict}

In spite of the definition of Valencian as the language of the Valencian Community, its linguistic enclosure is a controversial issue. Because it is similar to the Catalan, the majority of the linguists considered it as a dialect of this last one. In the Valencian Linguistic conflict, the inhabitants of Catalonia maintain their opinion that Valencian and Catalan are two versions of the same language and plead for the use of the same standard with three variants (Catalan, Valencian and Balearic), based on the fact that Valencian and Balearic are subordinated to Catalan.

This way of thinking is not common with the majority of the Valencian speakers, which shall consider their language as unique and independent from the Catalan. But, neither the Status of Autonomy from 1982, nor the Law 4/1983 regarding the use and teaching of Valencian language, gives the freedom of the recognition of the status of the Valencian language as an independent one. This legal problem gave birth to the conflict between the two models of standardization of the language, conflict which has continued until 1998, when the Valencian Government has approved the setting up of a new body, The Valencian Academy of Language, which purpose was to establish a set of rules for the use of Valencian language. ${ }^{28}$

It is difficult to establish accurately the degree of similarity between the Valencian and Catalan. The general idea is that the fact that the Valencians can understand Catalans and vice versa. Finally, the idea of this conflict is a political one. Apparently very recently, some political "nationalist" movements with a strong desire to be independent from the Spanish State, they have started to make their voice heard in some of the autonomous communities in Spain. Catalonia is one of them, where there is a significant presence of separatist nationalist movements.

The Catalan Nationalism tries to build a political project called "The Catalans Countries" (Països catalans). For many years, the Catalan Nationalism has invested large sums of money in the propaganda, inside and outside of Spain in order to make the rest of the population to believe that the valencian language is a dialect of Catalan and consequently, the Valencian society and its territory are part of the "Catalan nation" and are also part of the so called "The Catalans Countries".

The Catalan nationalists try to promote this project as being an exclusively linguistic one, hiding the real political meaning. They want a social and political absorption of the Valencian Community inside Catalonia in order to give it a higher political, social and territorial force to the ambitions of Catalan nationalism. ${ }^{29}$

\footnotetext{
26 "Historia del Valenciano", accessed June 10, 2015, http://www.idiomavalenciano.com/historia-delvalenciano.html

${ }^{27}$ Ibid.

28 "Conflicto político de la lengua valenciana", accessed June 10, 2015, http://www.idiomavalenciano.com/conflicto-politico-de-la-lengua-valenciana.html ${ }^{29}$ Ibid.
} 
This concept of "Catalan countries" can have different meanings depending on the context. Broadly, can be divided into two groups: linguistic or politic. The political definition of the concept is larger, because it includes by default the linguistic sphere. From the politically points of view, it refers to a number of projects endorsed by supporters of Catalan independence. They argue, on the basis of the linguistic fact for the creation of a common identity that goes beyond territorial limits of Catalonia and for political cooperation between the regions that are part of "Catalan Countries".

Thus, the cultural term used narrowly by Catalans philologists became highly controversial, more in the Valencian Community, since 1980. Some Valencians tend to believe that the concept was meant, in fact, to increase the strength of Catalonia in order to be able to win the independence, and to have the possibility to "annex" Valencia. But, because in Valencia there is a certain sense, even if not very strongly expressed, of their own identity, and it's not linked to Catalonia, they are in great disagreement with the possibility of establishing the so-called "Catalan Countries", political project.

\section{Conclusions}

The sociolinguistic situation of Valencia is, in many ways, unique: the Catalan is spoken in the most part of its territory since the thirteenth century, after being conquered by the Christian settlers and occupied by the Catalans (and other peoples less numerous). Until 1970 the Valencian language was used only familiar context or in a colloquial way, despite the fact that its use and teaching have been officially banned since 1707 .

In 1977, Spain became a democracy and for many people it seemed that this is a good opportunity to reactivate the question of Valencian identity and language. Although the official use of language and the teaching were reintroduced in Valencia in 1983, this language has lost its speakers constantly, not so much in absolute terms as in relative. Surveys show that today - thanks to the introduction of the Valencian language in the education system - more and more young people can write, speak and read in Valencian, than before, although very few uses the Valencian language.

Between 1980 and 1990, the right-wing parties and the media insisted that there is a plan for the replacing the genuine Valencian identity and Valencian language with a version of "Catalan". In what followed, "to be a good Valencian" meant to resist such a plan, and therefore to be completely against Catalonia, where possible. Of course, being against those whom language you share can hardly be "sensitive" if you aspire to "reborn" such a language - or simply to help her survive. Even worse, opposing yourself to this plan of "catalinisation" of Valencia meant, in fact, to be opposed to all efforts to "revive" the traditional language, such as standard modern language was discredited because it would be inauthentic. This prevented the spread of the language.

In theory, this conflict ended in 1998 through a compromise between the Spanish right-wing party (People's Party) and the Catalan parties who ensured the unity of language, although the Valencian politicians were careful to never recognize explicitly any unity of language. As a result, currently two thirds of the Valencian believe - or want to believe - that Valencian and Catalan are not the same language.

On the other hand, the Spanish State also opposes to the Catalans desire to earn independence and would not want their numbers to grow, just for this reason. If the unity of Catalan / Valencian is recognized, the "Catalan Countries" project becomes a political one and having an official base, then the Valencian Community would be part of it, and the Catalan force would increase considerably. 


\section{References}

$\checkmark$ Iñigo Urrutia; Xabier Irujo, ,The Basque Language in the Basque Autonomous Community (BAC)" in The Legal status of the Basque Language today: One Language, Three

Administrations, Seven different Geographies and one diaspora, ed. Gloria Totoricagüena and Iñigo Urrutia, 2008, accessed June $1^{\text {st }}$, 2015, http://www.euskonews.com/0463zbk/ene_120.pdf

$\checkmark$ Höfer, Karel (2012): Valencian Identity, Language and Language Policy, alppi.vedeckecasopisy.cz/publicFiles/00186.pdf, accessed June 10, 2015

$\checkmark$ "Conflicto político de la lengua valenciana", accessed June 10, 2015, http://www.idiomavalenciano.com/conflicto-politico-de-la-lengua-valenciana.html

$\checkmark$,Other Languages in Spain”. Accessed May 25, 2015. http://www.donquijote.org/culture/spain/languages/other-languages-in-spain

$\checkmark$ "Catalan Language. General Overview", accessed May 28, 2015, http://www.orbilat.com/Languages/Catalan/Catalan.html

$\checkmark$ "Catalan Language. General Overview", accessed May 28, 2015, http://www.orbilat.com/Languages/Catalan/Catalan.html

$\checkmark$ "Historia del Valenciano", accessed June 10, 2015, http://www.idiomavalenciano.com/historiadel-valenciano.html

$\checkmark$ "El Castúo", accessed May 27, 2016, https://sites.google.com/site/lacastua/el-castuo

$\checkmark$ "Pompeu Fabra", accessed June 1", 2015, http://www.lletres.net/pla/fabrapla2.html

$\checkmark$ "Galician (Gallego)", accessed June $1^{\text {st }}, 2015$, http://www.omniglot.com/writing/galician.htm

$\checkmark$ "Basque (Euskara)", accessed June 1 ${ }^{\text {st }}, 2015$, http://www.omniglot.com/writing/basque.htm

$\checkmark$ "Cultura Catalana. Lengua" accessed June 1st, 2015, http://www.llull.cat/espanyol/cultura/llengua_catala.cfm

$\checkmark$,Origen del valenciano”, accessed June $2^{\text {nd }}, 2015$, http://www.idiomavalenciano.com/origen-delvalenciano.html

$\checkmark$ „Estatuto de Autonomía del Principado de Asturias”, Article 4.1, accessed May 25, 2015, http://www.congreso.es/consti/estatutos/estatutos.jsp?com $=65 \&$ tipo $=2 \& i n i=1 \&$ fin $=9 \& i n i \_s u b=1$ \&fin_sub=1

$\checkmark$ „Estatuto de la Autonomía. Estatuto de Aragon”, Article 4.1”, accessed May 25, 2015, http://www.estatutodearagon.es/estatuto_de_autonomia

$\checkmark$ Estatuto de Autonomía de la Comunidad Valenciana”, Article 6.1, accessed May 25, 2015, https://www.boe.es/buscar/act.php?id=BOE-A-1982-17235 